\title{
Heritage Agencies and the Conservation of Brazilian Modern Masterpieces: A Partial Report
}

\author{
Carlos Eduardo Dias Comas
}

Faculty of Architecture, Universidade Federal do Rio Grande do Sul, Porto Alegre, Brazil

Email:ccomas@uol.com.br

\begin{abstract}
Heritage agencies have been protecting modern architecture in Brazil since 1948, starting with Oscar Niemeyer's Pampulha Chapel. So far 75 modern works have been listed mostly because of their artistic value. Listing prevents demolition. Unfortunately, it does not ensure proper conservation, and many interventions have disfigured works of architecture listed as modern masterpieces. Among those tolerated by the Brazilian heritage agencies, an early one is the roofing of the balconies of Oscar Niemeyer's Ouro Preto Grand Hotel. Among those approved were the construction of theatres diverging from those designed but unexecuted the time of the listing, and renovations associated with the introduction or updating of air conditioning systems. The former included one by Niemeyer himself, at his Ibirapuera Park complex, and another at Affonso Eduardo Reidy's Museum of Modern Art of Rio de Janeiro. The latter included the Pampulha Dance Hall, two Ibirapuera Park Pavilions, and the Planalto Palace. The paper analyses these retrofits along with the restoration project of Reidy's Pedregulho Housing Estate, and discusses the connections of the heritage agencies' stands regarding these interventions with scientism and the traditions of the conservation field. It suggests a bias of the agencies toward affirmation of historical values and celebration of picturesque disorder, and defends the need for their reorientation towards affirmation of the modern compositional logic.
\end{abstract}

KEYWORDS modern architecture, heritage agency, Brazil, conservation case studies

Received April 10, 2018; accepted June 6, 2018.

\section{SPHAN, DPHAN, IPHAN and Other Heritage Agencies in Brazil}

Brazil Builds: New and Old 1652-1942 (Goodwin and Kidder-Smith 1942) is the title of the 1943 exhibition at MoMA that publicised the emergence of a Brazilian school of modern architecture led by Lucio Costa (19021998) and based on Rio de Janeiro (Comas 2002). Surprisingly, given the revolutionary stance of modern architects elsewhere, Costa and his colleagues were also staunch supporters of SPHAN-Serviço do Patrimônio Histórico e Artístico Nacional, an agency of the Ministry of Education founded in 1937 to protect the Brazilian heritage, presided by Rodrigo Mello Franco de Andrade (1898-1969) until 1967. Indeed, Costa would soon be employed by the agency, as many other talented modern architects, including for a while Oscar Niemeyer (1907-2012); Costa would become Director of Studies and Listings in 1946, a position he kept until his retirement in $1972^{1}$. Mello Franco de Andrade was a lawyer by training, but most of his successors have been architects, remarkable exceptions being graphic designer Aluisio Magalhães (1927-1982), president from 1979 to 1982, who emphasised the recognition of cultural goods by their social value instead of their esthetic values or erudite characteristics, and historian Katia Bogéa, who was inaugurated in 2016, the first president to rise from the rank and file (Schlee 2017a, 2017b).

In its 80 years of existence, the agency changed names many times, as shown in its informative web site, www.iphan.gov.br. It became DPHAN-Diretoria do Patrimônio Histórico e Artístico Nacional in 1946, and IPHAN-Instituto do Patrimônio Histórico e Artístico Nacional in 1994. It is now sub-ordinated to the Ministry of Culture instead of the Ministry of Education. With headquarters in Brasilia and Rio de Janeiro, the agency comprises twenty-seven state-based branches, called Super-intendências, and twenty-seven city-based offices 
around the country, called Escritórios Técnicos, plus four special units, one in Brasilia (Centro Nacional de Arqueologia, dealing with the conservation of archeological remains), and three in Rio de Janeiro (Sítio Burle Marx, where the famed landscape architect lived and worked, a kind of botanical garden and plant nursery; Paço Imperial, the former viceregal and imperial administrative center turned into an exhibition gallery; a museum for folklore and popular culture, Centro Nacional do Folclore e Cultura Popular). The major divisions of IPHAN are DEPAM, the Department of the Material Heritage, and DPI, the Department of Immaterial Heritage, which work with members of the Advisory Council in two sectorial chambers, one for Architecture and Urbanism, the other for Immaterial Heritage. Chaired by the agency's president, the Advisory Council is composed by thirteen representatives from the civilian society, three representatives from ministries (Education, Tourism and Cities), two from federal agencies (IBRAM-Instituto Brasileiro de Museus, dealing with museums, and IBAMA-Instituto Brasileiro do Meio Ambiente e dos Recursos Naturais renováveis, dealing with the environment), and four from national professional associations of architects, archeologists, and anthropologists, along with the Brazilian branch of ICOMOS (International Council on Monuments and Sites). The Advisory Council has always been IPHAN's maximum authority regarding listings. Protected cultural goods were from the outset listed in four books, called Livros do Tombo.

The first book is Livro do Tombo Arqueológico, Etnográfico e Paisagístico, the Book of Archeological, Ethnographic and Landscape Listing, where cultural goods are registered because of:

a. their archaeological value, as vestiges of prehistoric or historical human occupation;

b. their ethnographic or reference value for certain social groups;

c. their landscape value, encompassing both natural areas and manmade places including gardens as well as cities or architectural ensembles.

The second book is Livro do Tombo Histórico, the Book of Historic Listing, where cultural goods are registered because of their connections with memorable events or moments in the history of Brazil, comprising real estate (buildings, farms, landmarks, fountains, bridges, old downtowns, for example) as well as chattels (images, furniture, paintings and woodcuts, among other pieces). The third book is Livro do Tombo das Belas Artes, the Book of Fine Arts Listing, where cultural goods are registered because of their artistic value above and beyond any utilitarian traits, including exceptional works of architecture. The last book, Livro do Tombo das Artes Aplicadas, the Book of Applied Arts Listing, is where cultural goods are registered because of their artistic value in association with its utilitarian function, including some kinds of architecture, as well as examples of the decorative arts, graphic arts and furniture.

Anyone can propose a listing to IPHAN, from within the agency or outside it, as long as the request is accompanied by written and graphic documentation justifying the proposal. DEPAM analyses the request, and submits its conclusions to the Chamber of Architecture and Urbanism. The conclusions will be exposed and discussed in public hearings, and a certain amount of time is allotted for eventual contestation and judicial appreciation. Then the dossier is submitted to the Advisory Council, which hands it to one of its members for analysis and report, followed by written and verbal presentation, discussion and voting. State heritage agencies complement the mission of the national heritage agency since the $1960 \mathrm{~s}^{2}$, and municipal heritage agencies since the 1980s. They all follow the national agency lead in procedural matters.

\section{Listing Modern Masterpieces}

The national agency listed for the first time a modern building in 1947, Niemeyer's Chapel of St. Francis of Assisi at the Pampulha complex, a garden suburb of Belo Horizonte. It had been completed two years before, and was menaced of demolition by the municipal authorities. Recommending the chapel's listing in the Fine Arts Book, Costa said the building had become a 'precocious ruin' (Costa 1999), notwithstanding its reception as a masterpiece by prominent intellectuals in the country and abroad. The following year the agency listed in the Fine Arts Book the monumental Ministry of Education, by Costa and a team including Niemeyer and Affonso Eduardo Reidy, at once reinforcing the status of the modern architects at the agency and protecting the building, designed in 1936 and inaugurated in 1945, against eventual disfigurement. One decade later, Costa asked for the listing in that same book of the Seaplane Station of Rio de Janeiro, designed and built from 1937 to 1938 by Attilio Correa Lima, Renato Soeiro, Jorge Ferreira, Renato Mesquita e Tomás Estrela, and menaced of demolition by the imminent construction of a coastal highway. The wood building that housed the President of Brazil during the construction of Brasilia was listed in the Historic Book in 1959. Two preventive listings in the sixties involved 
incomplete works, Niemeyer's Brasilia Cathedral and the Flamengo Park, with gardens by Burle Marx, and buildings by Reidy, including the Museum of Modern Art of Rio de Janeiro, one of the links connecting the Carioca ${ }^{3}$ School, of purist connotations, to the later Paulista School, of brutalist connotations (Zein 2005; Comas 2015, 40-67). The Cathedral was listed in the Fine Arts Book; Flamengo Park, in the Landscape Book.

No building was listed during the Magalhães administration, modern or otherwise. The pioneering Modernist House of 1930 by Gregori Warchavchik in São Paulo, and the Brazilian Press Association headquarters (ABI, in Portuguese) by Marcelo and Milton Roberto were listed in the Fine Arts Book during the 1980s, along with two Costa buildings of the 1940s, the Nova Friburgo Park Hotel and the Guinle Park Apartments, and the Burle Marx Estate. The Pilot Plan of Brasilia and the Pampulha complex were listed in the 1990s both in the Fine Arts and the Landscape Books, along with another pioneering work, the University Morgue by Luís Nunes in Recife, of 1937, listed in the Fine Arts Book. In the new century, listing so far has privileged Niemeyer and Lina Bo Bardi. The 27 protected works of the former include the Government Palaces and many buildings in Brasilia along with his house in Rio and the Ibirapuera Park Complex in São Paulo; the four protected works of the latter are the Museum of Art of São Paulo, her own house, the SESC Pompeia Leisure Centre, and the Oficina Theater. Works listed in the Historic, Fine Arts, and Landscape Books comprehend a company town of the 1950s (Vila Serra do Navio by Oswald Arthur Bratke in Amapá), and an urban complex (Cataguases, a small town close to Rio featuring interesting work of the 1940s and the 1950s by Niemeyer, the Roberto Brothers and others), as well as a memorial (the Monument to the Dead of World War II in Flamengo Park by Marcos Konder Netto and Helio Ribas Marinho, 1957-60). The Castro Alves Theater by Bina Fonyat in Salvador, dating from the 1960s, was listed in the Historic and Fine Arts Books. As noted, state and municipal listings complement the national listing; some predate the federal listing, a relevant example being the Ibirapuera Park, listed by CONDEPHAAT_Conselho de Defesa do Patrimônio Histórico, Arqueológico, Artístico e Turístico, the heritage agency of the State of São Paulo, in 1992. That does not mean that the federal recognition would not be welcome for highlights of the Paulista school such as FAUUSP, the School of Architecture of the University of São Paulo, by Vilanova Artigas, or the Clube Atlético Paulistano Gymnasium by Paulo Mendes da Rocha, protected at the state and municipal levels only.
Anyway, the major surviving works of the Carioca school and some works of the subsequent Paulista school are now listed, and cannot be demolished without permission from the heritage agencies. Listing is no longer controversially preventive. Brazilian modern architecture is already fifty years of age or close to it. Its works are ancient enough to warrant deliberate conservation and, if conserved, recycling responsive to cultural changes, retrofit to comply with technological advances and stricter codes; it is generally accepted that the best method of conserving a historic building is to keep it in active use (Ireland 7.3.1). Listing is not conservation. It prevents outright demolition, but not ruination, which is piecemeal demolition, even if considered a natural fate and therefore acceptable for the likes of John Ruskin (Ruskin 1849, 146-154). All the same, listing theoretically sets the guidelines for interventions in listed buildings. Those should be justified, at least partially, by the requirements of conservation; they should fight decay, avoid injury, and preclude loss. Since it became IPHAN, the national heritage agency has no funds of its own to pay for conservation work of whatever kind; state and municipal agencies never had them. All of them have been understaffed. Yet they are not powerless, for their cadres have the last word in any alteration of listed buildings.

Owners and their architects can propose whatever alteration they might wish; they cannot overrule the heritage agencies' verdicts on their proposals. Nevertheless, these verdicts can be problematic: in the last decades, heritage agencies have tolerated or approved interventions that disfigured works of architecture recognised as modern masterpieces in their listings. They were mischaracterised, robbed of a distinctive trait, devalued. Their artistic integrity-once called beauty-was impaired at the level of both multisensory perception (which includes vision and touch, image and substance, and cannot be reduced to either element of those pairs) and intellectual stimulation (substance of another sort).

\section{Exemplary Case Studies}

Sadly, architects can disfigure their own work, or add to previous disfigurement, as Niemeyer did in several cases. It can be a minor offense, like the replacement by seamless concrete of the beautiful stone pavers and pebble joints at the terraces of his house at Canoas Road (1953), in Rio de Janeiro, in a reform done in the 1970s, well before its listing. But it can affect the whole work, as in the case of the Ouro Preto Grand Hotel (1941-1944). Ouro Preto was a colonial mining town, the former capital of the state of 


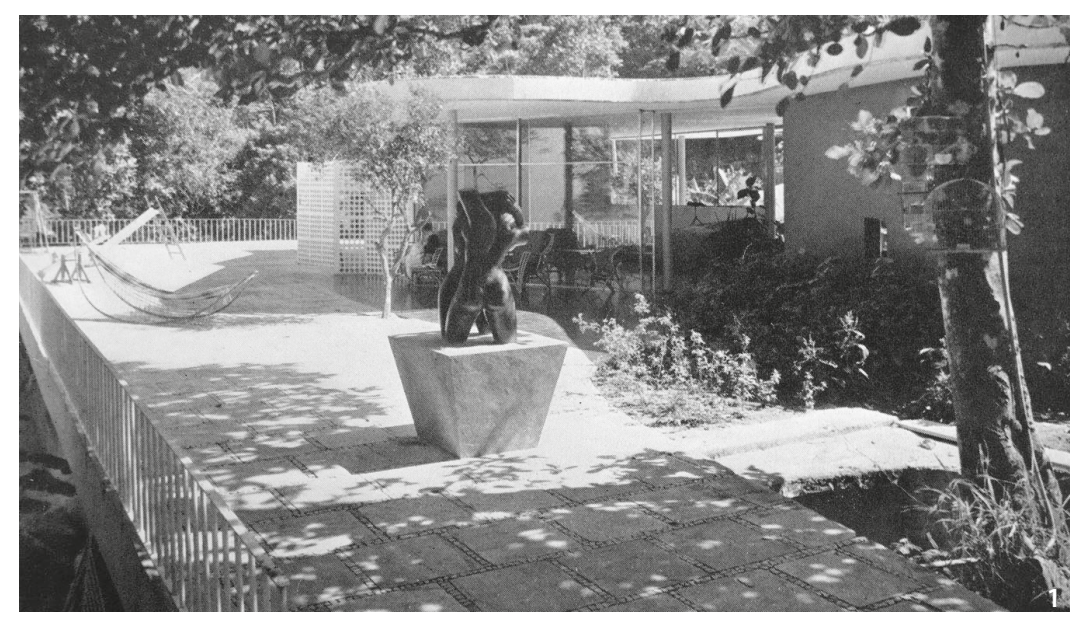

Figure 1 Oscar Niemeyer, House at Canoas Road, Pavers and pebbles (Source: Papadaki 1956, 77). Figure 2 Oscar Niemeyer, House at Canoas Road, concrete floor after 1970 reform (Source: Leonardo Finotti).

Figure 3 Oscar Niemeyer, Ouro Preto Grand Hotel, view with original endwall (Source: Mindlin 1956,
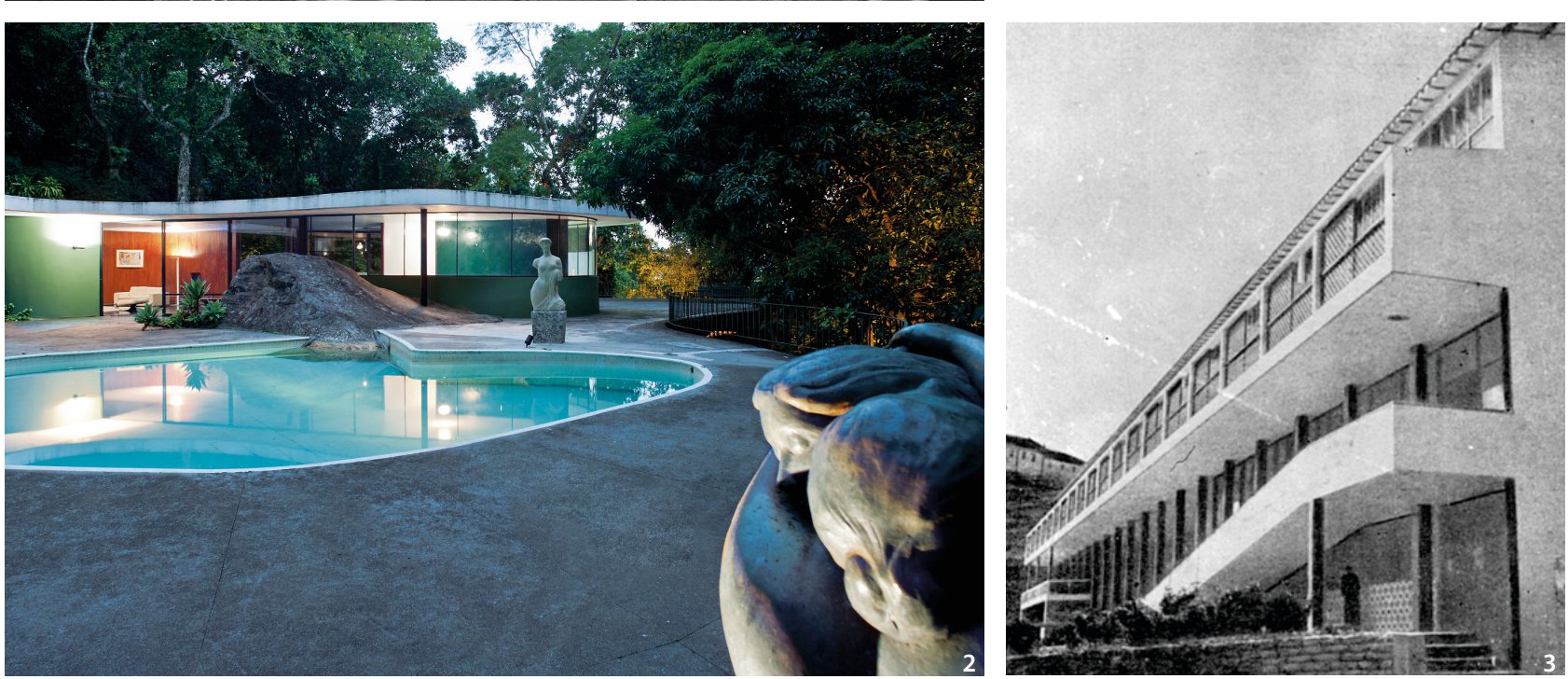

Minas Gerais, proclaimed a National Monument in 1933, before SPHAN was created. The construction of the hotel was the mayor's initiative, and it was meant to be major urban equipment, as the adjective 'grand' indicated. Niemeyer's project was exemplary, a long four-storey slab building on a steep hillside, echoing the Palace of Governors on the hilltop. The rear elevation, facing the slope, is a calm low relief affair. Unlike the rear elevation and the aligned townhouses across the street, the front elevation is a riot of protruding and receding volumes, double and triple height colossal stockades, and a void crossed by a public route. The monopitch tiled roof bowed to context, as did the detailing of the wood trellises, painted colonial blue, and the concrete pillars painted in a woodsy shade of brown. These inflections relate to the historic setting by analogy (the pillars) as well as replication (the trellises), or gradation (the roof). In both cases they show other possibilities of relationship between new and old architecture than the usual contrast between modern planarity and pre-modern texture. Indeed, as the photo in Brazil Builds shows (Goodwin and Kidder-Smith 1943, 133), Niemeyer inverted that relationship, playing the laciness of the front elevation against the whitewashed surfaces of the neighboring townhouses (Figure 1-3).

The Grand Hotel was not listed individually, but included in the Ouro Preto listing. Its disfiguration started when the balconies of the apartments were roofed with tiles prolonging at a slightly different kevel the original monopitch, and nobody paid attention to it. IPHAN has been understaffed almost from the outset. As a result, the blank side elevations lost the serrated profile that made the hotel resemble a broken geode, and the front elevation acquire the flavor of an internal view. In Niemeyer's 1993 proposal for remodeling the hotel, the roofing would be kept, and the balconies enclosed with hexagonal openings, not unlike the kind of openings that could be seen in contemporary Niemeyer's projects, such as Rio's CIEP schools. The pronounced formal contrast with the original hotel made it clear that Niemeyer was meeting his younger ego in a new stylistic phase $\mathrm{e}^{4}$. The dynamic formal 


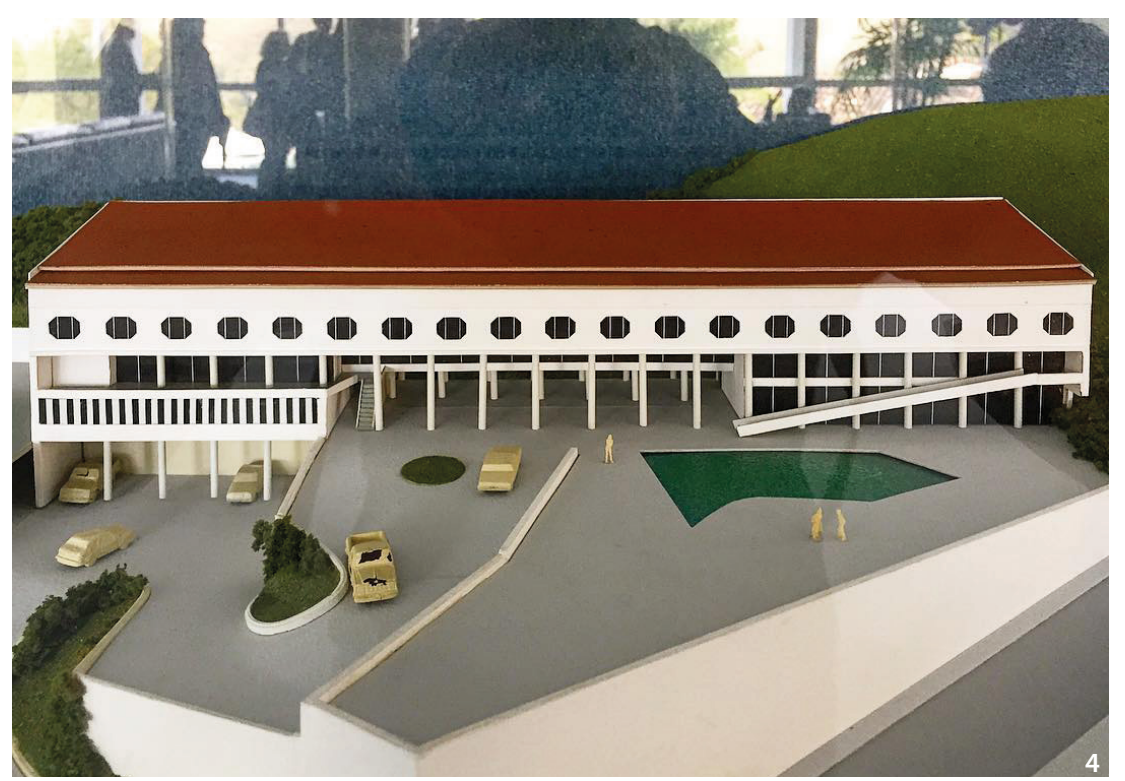

Figure 4 Oscar Niemeyer, Ouro Preto Grand Hotel, model of 1993 reform proposal (Source: Rodrigo Queiroz). complexity of the 1940s would disappear, as if straitjacketed or overwritten. To worsen things, the proposal was just a cover-up for adding another block to the rear of the existing volume (Comas et al. 2008, 103-108) (Figure 4).

In that sense, IPHAN architects prevented the worst, but the old scars remain, and to them was added one module of the new balcony, built as a test. Niemeyer's proposal may seem to have been refused on the grounds of the artistic integrity of the original work. Yet, no measures were taken to effectively restore the hotel to its former glory, when that would have been so simple: a lot of cleaning and coats of appropriate paint, besides the replacement of that tile roof doubling the height of the balconies by low-pitch polycarbonate sheets in the same level as the existing one-storey high beams and side wall indentation; still open, balconies could even accommodate individual air conditioning units in an unobtrusive way. IPHAN preferred to highlight historical values and romantic decay instead of defending the plastic coherence of the original solution.

Niemeyer struck again at the Ibirapuera Park in 2002 (Scharlach 2006). He refused to follow his own original plan, and was allowed to do a completely different auditorium from the one designed in 1952, unfortunately unbuilt at that time for political and financial reasons; equally unbuilt was the covered walkway that would have connected the auditorium, the big marquee and the domical Palace of the Arts, re-baptised in 2000 as Oca, an Indian hut. The new auditorium, a trapezoidal volume, has intrinsic architectural interest, but it does not relate to the earlier composition. It stands on axis with the dome whose geometric minimalism it shares, but the marquee advances between them. Niemeyer wanted then to demolish the tip of the marquee, arguing that it did not harmonise with the new auditorium, and that it prevented the creation of a suitable entrance plaza, two assertions open to much debate ${ }^{5}$. Although the architect exerted his considerable influence in order to get his fancy fulfilled, including a most awkward walkway between Oca and the new auditorium, the conservation agencies prevented that in 2004, on the reasonable grounds that a listed project belongs to the community and not to its author. The situation raised questions about the validity of listing an incomplete project without articulating sensible guidelines for its completion, but incompletion seems to have been valued for its own sake both when the new auditorium was approved and when the demolition of the tip of the marquee was rejected. For incompletion too is romantic, speaking of historical vicissitudes and the passage of time.

Paulo Mendes da Rocha and his young collaborators reformed Oca in 2000 without controversy (Artigas 2007, 154; SPBR 2000). Oca is the rounded counterpoint to the $250 \mathrm{~m}$ long Palace of the Industries behind, now the Bienal Pavilion. This is a box of rectangular parallel plate floor slabs cantilevered on a grid of point supports enlivened by a curvilinear void along the longitudinal axis in one extremity, where a ramp rises supported by a surreal treelike column. Oca appears as a dome lifted from sci-fi movie of the 1950s, over circular parallel plate floor slabs cut at the borders to generate surreal voids: the uppermost roof slab resembles a rectangle with concave curvilinear sides, and the second a similarly distorted regular hexagon; the ground floor has two asymmetrical cuts giving a glimpse of the basement below. One of these voids 

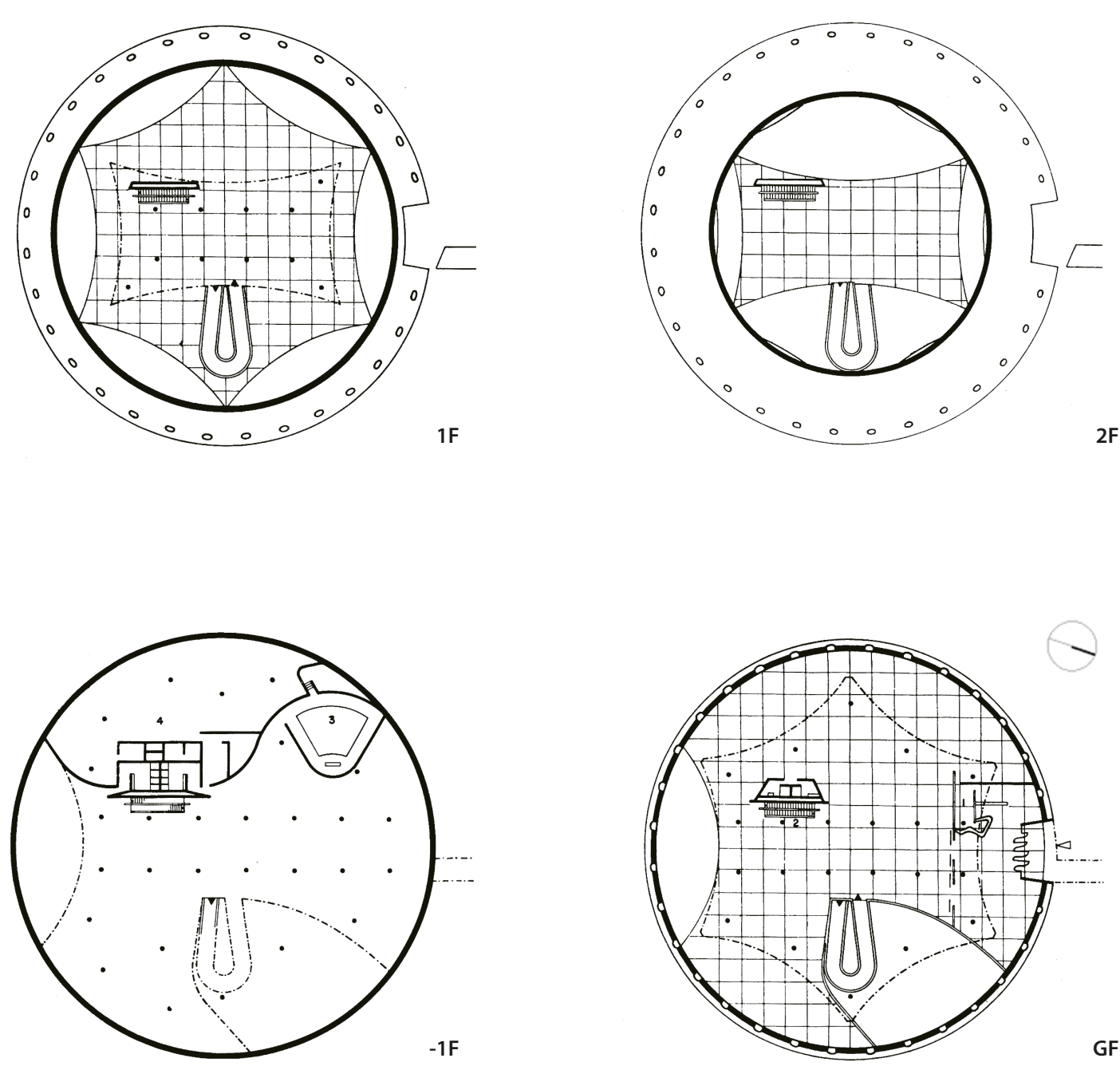

Figure 5a Oscar Niemeyer, original plans of Palace of Arts (Oca). (Source: Mindlin 1956, 188).

accommodates a horseshoe ramp; all of them contrast with a surprising straight alley on the entrance axis, lined by parallel rows of cylindrical columns. The impact of that setup was enormous. As entrance was devoid of any obstacle, it sucked the visitor as it entered. At the same time, it directed his attention to the peripheral cutouts, sponsoring exceptional vertical episodes, and threw in evidence the planar roof slabs and the horizontally expanding space they generated (Figure 5a, Figure 5b).

Oca was to be a venue for large traveling exhibitions. Its original use was not changed. However, its particular requirements were no longer the same. New air conditioning ducts and electricity cables were needed to comply with contemporary standards of comfort and performance. Exposed rather crudely, like tridimensional grafitti, they mar the continuity of the ceiling and destroy the original assertiveness of the central alley. Perpendicular to its colonnades, a long balcony for the inspection and storage of visitors' bags adds to the loss of axial directionality. The setup is theoretically reversible, complying with one of the current restoration mantras, but it is not going away so soon (Figure 6).

Niemeyer had nothing to do with the Oca project, although answering to the programmatic challenges presented by its new operational requirements could have strengthened his plaza and marquee demolition proposal. He was not responsible either for the conversion of Ibirapuera's former Palace of Agriculture facing the Bienal Pavilion across the avenue, into the Museum of Contemporary Art of the University of São Paulo, MACUSP. Remarkable for its ground floor V-shaped columns, it had been for years the headquarters of the Transit Department of the State of São Paulo. The relatively low floorto-ceiling heights were not unsuited to the nature of the 


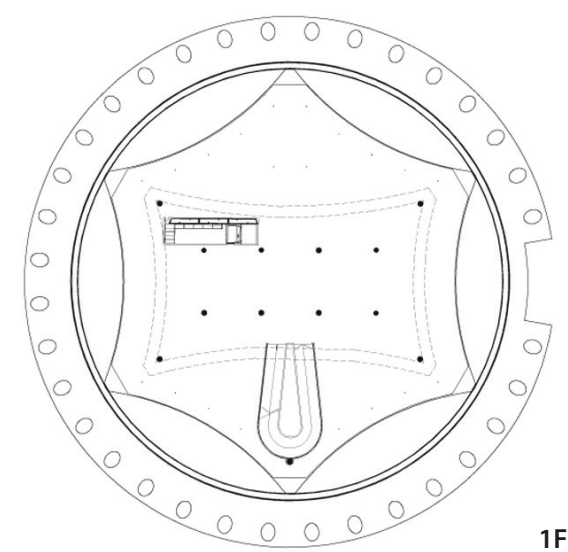

$1 \mathrm{~F}$
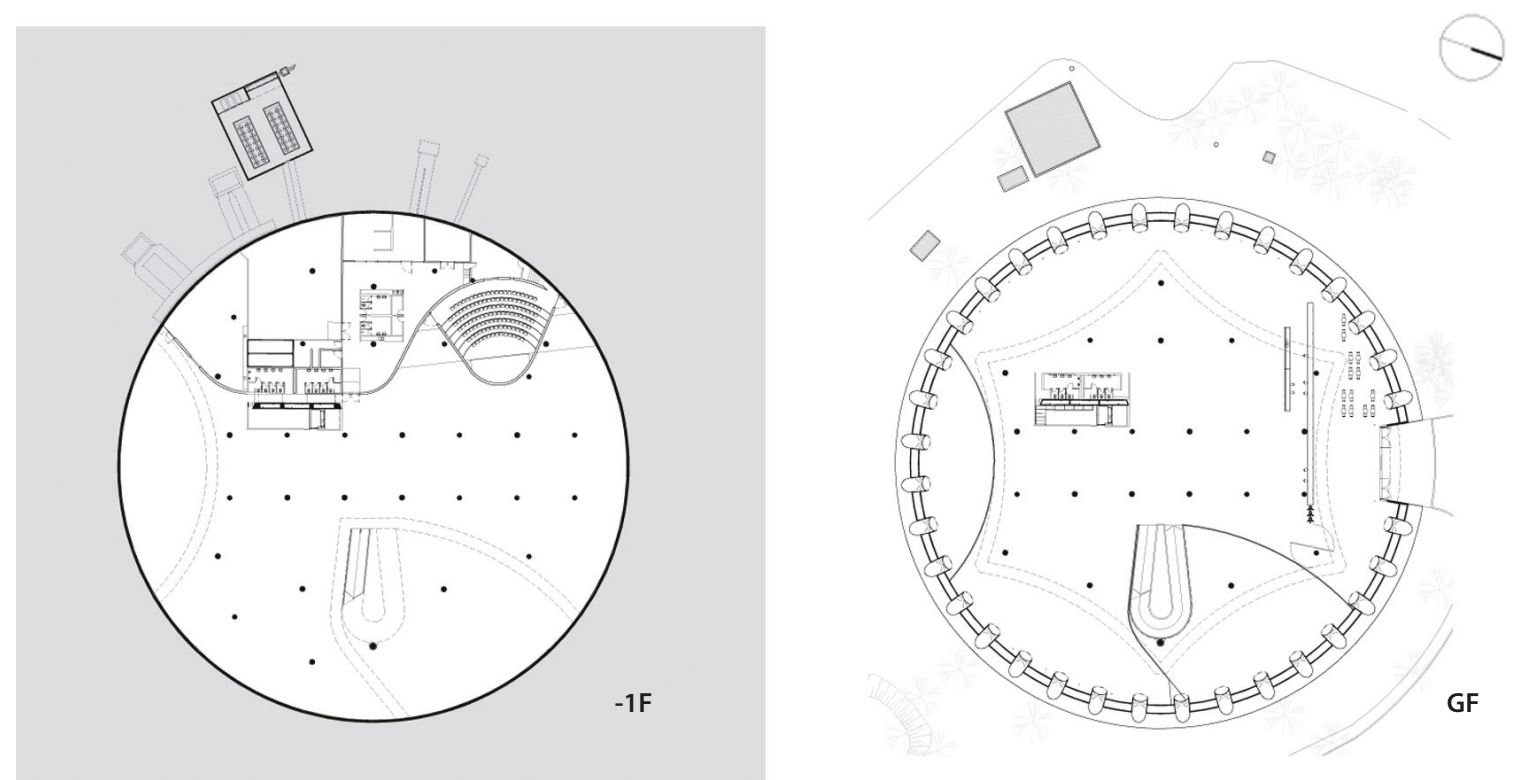

$5 b$

Figure 5b SPBR Arquitetos, 1999 reform plans of Palace of Arts (Oca) (Source: SPBR).

rich collection, consisting mostly of medium to smallsize paintings. Niemeyer had been hired in 2007 to do a reform project, which was shelved due to high cost estimates. The task was then assigned to a bureaucratic state agency, Companhia Paulista de Obras e Serviços. The depressing result, inaugurated in 2012, is a riot of claustrophobic dropped ceilings at several levels, to accommodate the ubiquitous air conditioning ducts and light fixtures, plastered glass walls and external fire escape staircases. The reform was approved despite initial protests of architects from the heritage agencies. There is such a thing as architectural abuse and harassment, and curators that should have known better can be the worst offenders, adding to the pressures of safety codes and demands of controlled environment (Figure 7, Figure 8).

It is unlikely that Niemeyer was consulted for the contemporary reform of Palacio do Planalto, the seat of

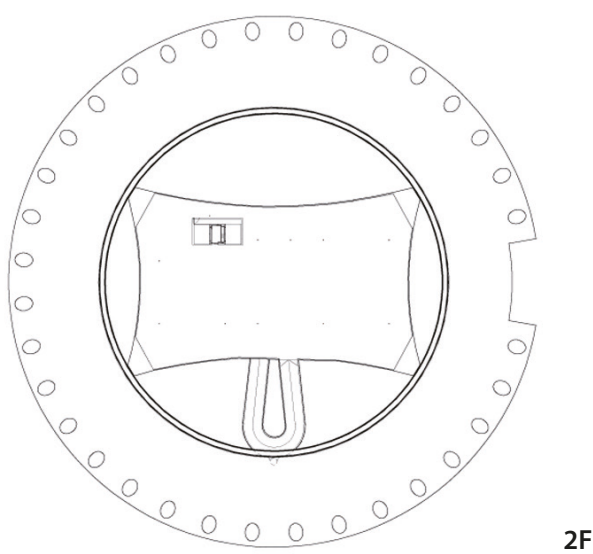

the Executive Branch of Brazilian government in Brasilia, given the public protests of the architect's office against the quality of that undertaking. An initiative of president Luiz Inácio Lula da Silva himself, it had been dutifully approved by IPHAN and carried out from 2008 to 2010. Air conditioning and fire escape requirements were this time compounded with the need for accommodating state-of-the-art live TV transmissions everywhere over the place, and a garage for 500 cars. No public hearings were conducted, for reasons of state. What can one say? That at the very least one level of the dropped ceiling should have been coordinated with the panes of the glass curtain wall? As in Oca, where change of use was a question of performance rather than of kind, the rationale for the reform was the combination of need and reversibility, even if that reversibility is highly hypothetical in the near future (Figure 9). 

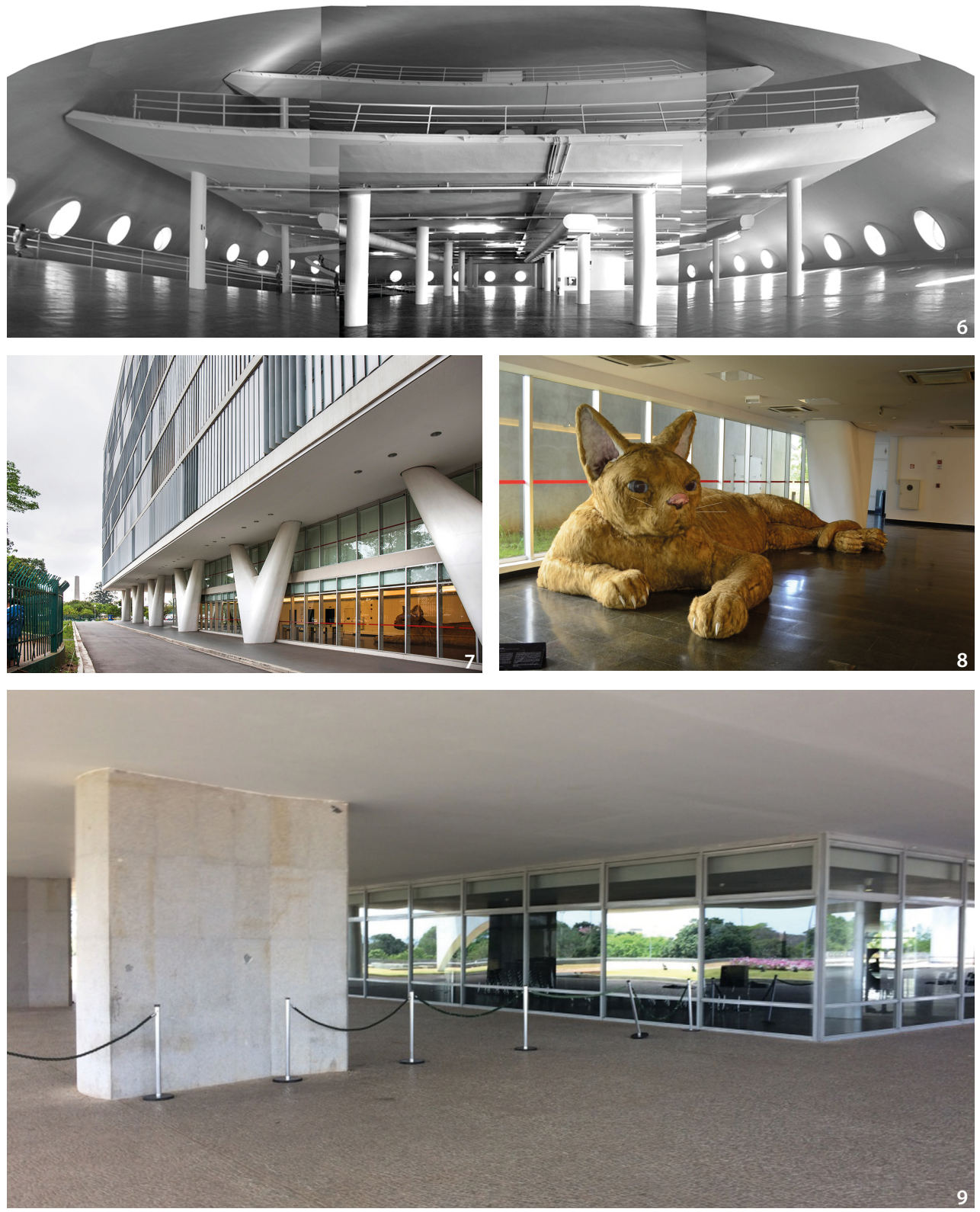

Figure 6 Oscar Niemeyer, interior of Palace of Arts (Oca) after reform (Source: Ruth Verde Zein). Figure 7 Oscar Niemeyer, external view of Palace of Agriculture (MAC-USP) with dropped ceilings (Source: the author).

Figure 8 Oscar Niemeyer, internal view Palace of Agriculture (MAC-USP) with dropped ceilings (Source: the author).

Figure 9 Oscar Niemeyer, external view of Planalto Palace with duct behind glass wall (Source: the author).

But Niemeyer did give his blessing to the conversion of the Pampulha Dance Hall into the Centro de Referência em Urbanismo, Arquitetura e Design de Belo Horizonte a gallery for exhibiting urban, architectural and design projects, and he recommended to local architects Rafael Hardy Filho and Mariza Machado Coelho the inclusion of an enclosed wedge-shaped auditorium in the quasicircular volume of the original hall, with diameter $20 \mathrm{~m}$. That intrusion breaks the hall's spatial continuity and does so needlessly, as acoustical privacy inside the auditorium is non-existent, and its Lilliputian size suggests that a temporary setup with movable chairs would be a reasonable alternative. As if that was not enough, a dropped gypsum ceiling hides the new air conditioning ducts, and it looks like cheap Art Déco, accompanied by pendant lamps taken out from the Jetsons comic strip: so much for the continuity of ceilings between the hall and the marquee, where the original embedded lamps remain to remind the visitor of past times. There is no way of confounding the new intervention with the original, but the full experience of the original is also lost for the sake of a temporal truthfulness, which might be considered either expression of illiteracy regarding modern architecture goals of outdoorindoor interconnection at the period, or post-modernist presumption (Figure 10-12).

The fate of another masterpiece is also tied to delayed execution of one of its elements. This is the case of Affonso Eduardo Reidy's MAM-Museum of Modern Art 

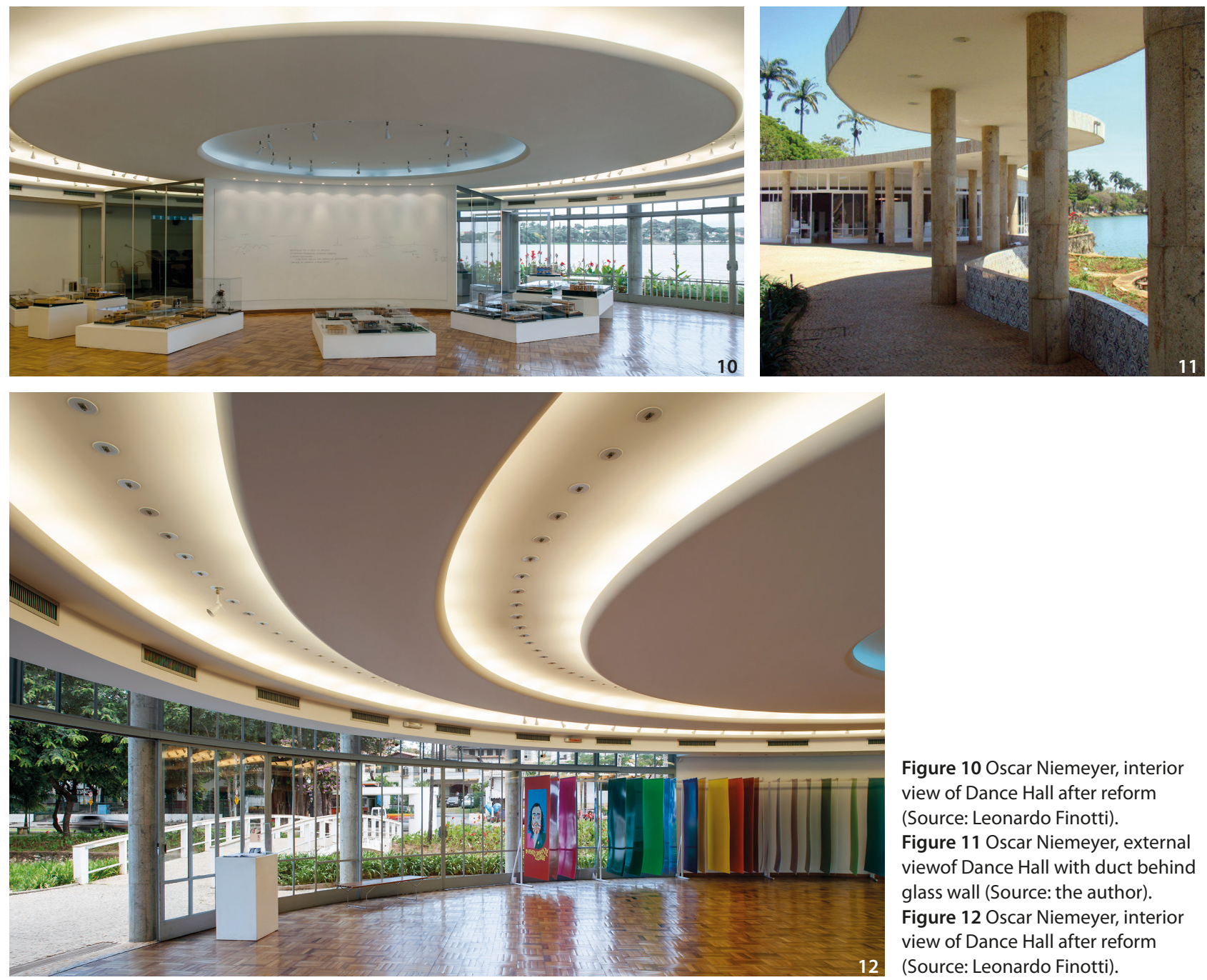

Figure 10 Oscar Niemeyer, interior view of Dance Hall after reform (Source: Leonardo Finotti).

Figure 11 Oscar Niemeyer, external viewof Dance Hall with duct behind glass wall (Source: the author). Figure 12 Oscar Niemeyer, interior view of Dance Hall after reform (Source: Leonardo Finotti).

in Rio de Janeiro (Bonduki 1999), designed in 1953 as an additive composition of three blocks, the school, the museum proper and the theater, inscribed into a platform abutting the museum, a terrace above and a portecochere below. The school was finished in 1957, and the museum in 1967; lack of funds prevented the construction of the theater, but the platform was built as a whole rectangle around 1968. A theater with a different program-a venue for concerts and shows-was proposed by private investors around 2003 and inaugurated in 2006. IPHAN architects fought for keeping the original volume above the platform, but they accepted the demolition of the ramp leading to its terrace, the greater occupation of the foyer below, and a truly sordid rear elevation, along with reinforced concrete that did not match the original. They could have been more relaxed more about that volume, and stricter about the other points. Meanwhile, large plastic tents on metal poles inhabit the terraces of the building like parasites, and the Board of Trustees does nothing; renting the terraces for parties is the institution's major source of income. In principle, they are temporary structures, but did they need to be such an ugly, unkempt, and constant presence? MAM-Rio could learn about different ways of displaying ready-made elements. After all, it is a museum of design too. On a more cheerful side, the museum block is in great condition-it was rebuilt in 1985 following the original project after a tragic fire that spared the structure only. Oval shaped and exposed air conditioning ducts similar to those found in Oca are not a problem. On the one hand, the structural exoskeleton means that there is no conflict between them and freestanding columns that define both linear and radial grids. On the other hand, they are carefully positioned below the nerved floor slabs, so as to appear integrated into a textured surface, or hidden into carefully plotted gypsum board ceilings. As a noted English critic observed in 1941, modern architecture is a weave of many styles (Summerson 1963, 212). Although Reidy's museum is 


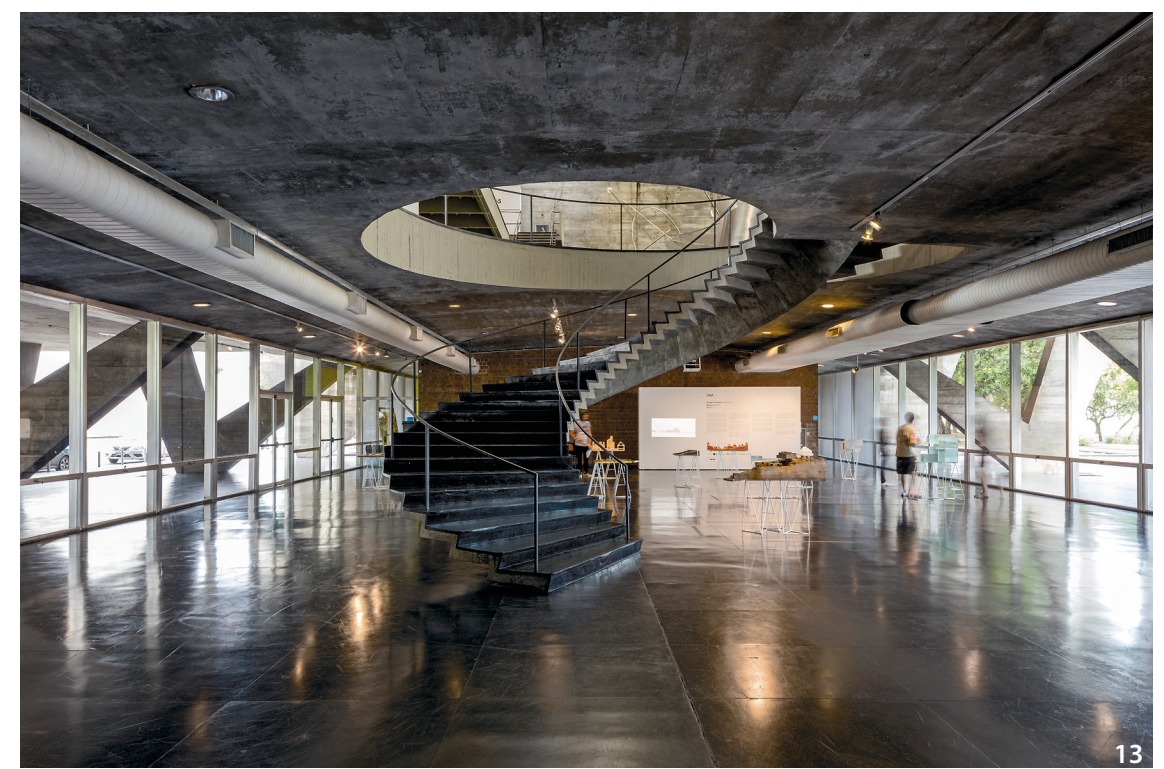

Figure 13 Affonso Eduardo Reidy, Museum of Modern Art, ground floor with ducts (Source: Leonardo Finotti). contemporary with Oca, it is epic instead of lyrical, belonging to a distinct modern family than all the Niemeyer's projects here cited (Figure 13, Figure 14).

Reidy's Pedregulho Social Interest Housing (19471953 ) is the exception in this series. Justly praised and badly kept, disfigured by life, so to say, it has been renovated sensibly from 2011 to 2015 by Alfredo Britto and team, people that do not see differences in principle between the restoration of a modern work of architecture and the restoration of any other work (Britto 2015). They used all the relevant prospection techniques and methods accepted in the field. Changes to Reidy's project included the total replacement of wood by aluminum windows with individual air conditioning units protruding from them, ratifying an ongoing process that residents saw as progress at the same time that it accepted economic realities. This was not a prestige operation like the restoration of the classy Pirelli Tower, which carried the banner of Italian-driven theories of conservation and their concern with the preservation of materiality against the more pragmatic American and German stands, as shown by another prestige operations, the restoration respectively of Lever House in New York, and of the Thyssen Building in Dusseldorf, which opted for the total replacement of their curtain-walls (Salvo 2002; Kuhl 2006; Salvo 2006; Salvo 2008). Restoration was understood here as renovation that brings the building to a good state of repair, approximating but not fully matching the original physical condition. Pedregulho became no less a cultural reference than it was (Figure 15). The result demonstrates that a mature understanding of the compromises demanded by inhabitation and budget does not necessarily lead to a reform betraying the original architectural concept and allying itself to gentrification, as is the case of the renovation of Park Hill in Sheffield, where two-thirds of the original 1,000 council flats will be for private sale, with the help of public subsidy to the development (Moore 2011).

\section{Learning from Experience}

All of the case studies here presented can be called reforms of existing buildings. All but Pedregulho are primarily retrofits, interventions that add a component or accessory to something that did not have it when manufactured or built. Some involve the addition of elements of construction and composition; some involve technological updates. Only Pedregulho qualifies as a proper restoration project. Nevertheless, all of them show that, in a crucial point, the restoration of or retrofit project for a modern building differs neither from similar projects for a non-modern building, nor from the architectural project for a new building. The choices they imply cannot help being the result of a political process, in which persuasion, prestige, power, intuition, knowledge, taste and belief, all play a part, not to mention budget and schedule. Restoration and retrofit projects can never be exact, the product of rigorously testable theories based on precise or absolute measurements. Too many incalculable variables enter into play in an unspecified number (Cartwright 1973) ${ }^{6}$. Too many actors are involved, their influence and authority often asymmetrical. The existence of different schools of conservation reinforces the point. For instance, the acceptable degrees of rifacimento and ripristino are not the same everywhere. Latins tend to follow the Venice Charter 

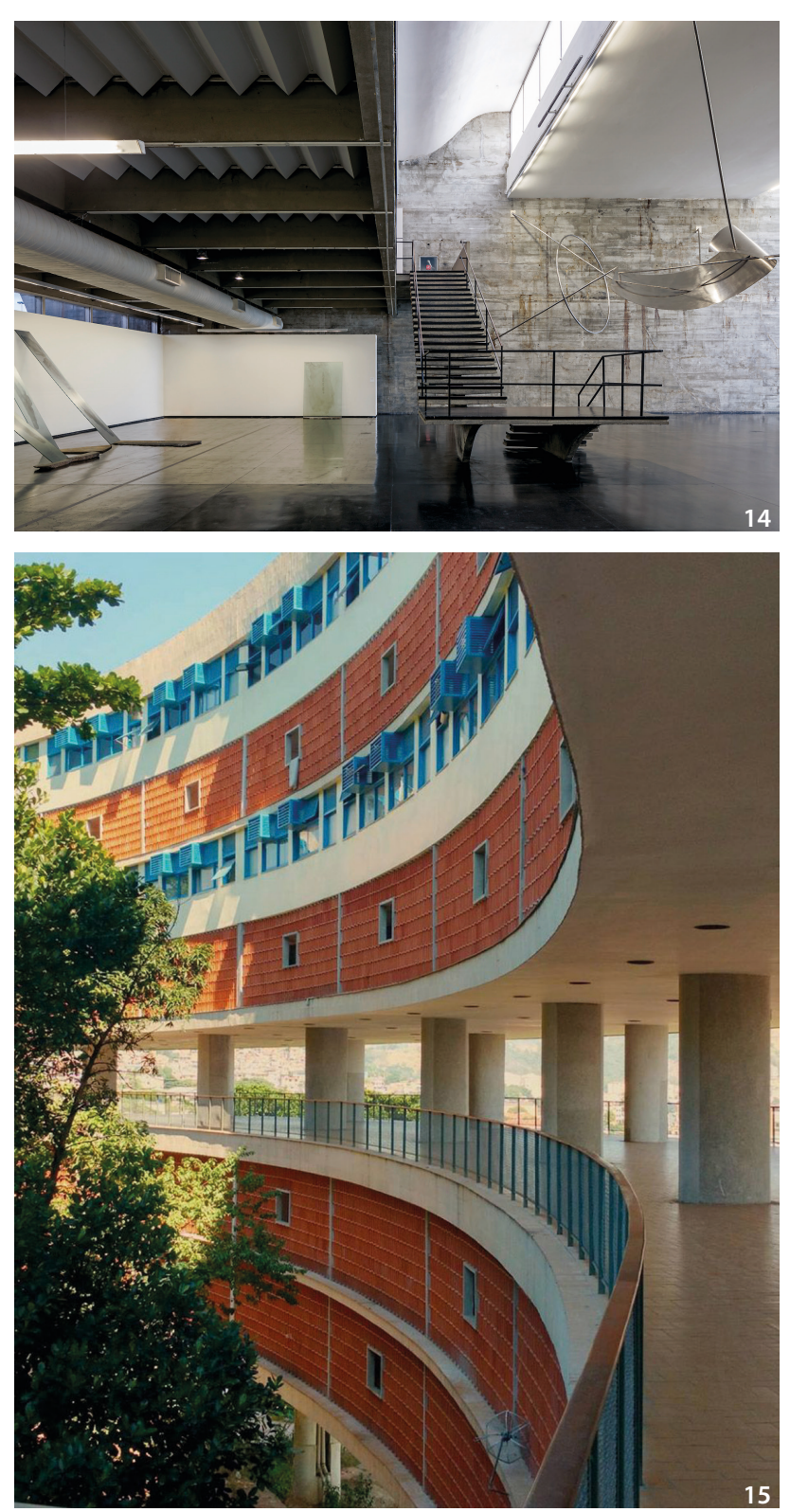

Figure 14 Affonso Eduardo Reidy, Museum of Modern Art, second floor with ducts (Source: Leonardo Finotti).

Figure 15 Affonso Eduardo Reidy, Pedregulho Social Interest Housing individual $A C$ units after restoration (Source: the author).

of 1964, particularly Italians and their Brazilian disciples; Anglo-Americans and Northern Europeans, the Burra Charter of 1999. Reactions to José Oubrerie's delayed completion of Saint-Pierre de Firminy were not unanimous, and too many criticisms forgot that he was from the outset a co-author of the project.

Scientism-the excessive belief in the power of scientific knowledge and techniques professed by many conservationists - is an ally of the romanticism behind the heritage agencies' attitudes towards the retrofits here presented. The appeal to science discredits discussion of design decisions and their authorship (Comas 1986, 33-46). The appeal to history discredits discussion of design decisions and their artistic quality. The former stresses the impersonalism of methodology. The latter stresses a documental character that tends to level in importance all interventions in a building's life. Taken together, they downplay the restorer's or the retrofit designer's artistic responsibility concerning the existing building and exaggerate it concerning any new element. A bias towards formal contrast is disguised as or confounded with the pursuit of historical authenticity in order not to fool historians, those credulous types. Emphasis is on picturesque, even disordered change: heteromorphism signals heterochrony, a way of endorsing stylistic eclecticism without guilt, further alleviated by demanding that new interventions be reversible, and potentially ephemeral. Generational change within the staff of Brazilian heritage agencies contributed to this alliance in the 1980s and 1990s, when criticism of the modernist legacy in patrimonial conservation rose. The denial of artistic value to eclectic $19^{\text {th }}$-century architecture seemed now indefensible at the level of taste as well as history, and so did the lack of scientific rigor in many restorations of colonial monuments. The very primacy of architecture in conservation efforts came under attack, as much as the primacy of the work of architecture seen in isolation, not to mention the understanding of architecture as a fine art, which was equated to elitist estheticism (Motta 1987; Fonseca 2005; Chuva 2009).

No wonder then that a veiled opposition was born in the Brazilian heritage agencies to the pursuit of architectural unity endowed with transhistorical value, even if aware that different parts of a building have different life spans (Comas 2007, 35-52). For it would lead to the minimisation of the marks documenting a building's past vicissitudes. It would have disavowed Camillo Boito and returned to Viollet-le-Duc, who proclaimed that 'to restore a building is not to preserve it, to repair, or rebuild it; it is to reinstate it in a condition of completeness which might never have existed at any given time' (Boito 1884; Violletle-Duc 1866, 14-34). Often vilified, seldom read with attention, the statement introduces a reflection that deserves a second look, because Brazilian modern artistic masterpieces were intended as unified compositions to be completed in a relatively short time-span, including Brasilia itself. They were not thought of as works-in-progress for centuries like Gothic cathedrals or Barcelona's Sagrada Familia. It is telling that Niemeyer did not forsake formal coherence in his less than fortunate renovation proposals for the Ouro Preto Grand Hotel and the Ibirapuera Park new entrance plaza. Last but not least, apart from Pedregulho, 
no example here discussed was in really bad shape before its proposed retrofit, and that was why they were candidates for retrofit in the first place instead of restoration.

Arguably, the opposition between Viollet-le-Duc and Boito has been overemphasised by the latter's disciples. The Frenchman had no qualms about demolishing stylistically diverse additions to medieval buildings, but he saw that absolute positions regarding the reinstatement of a unity of style in these buildings were unreasonable. Each case had its own peculiarities, making generalisations difficult. For instance, he welcomed the conservation of anachronistic technological improvements if they prolonged the livability of a building. Gutters in a $12^{\text {th }}$ century medieval church are always later additions, as they did not come in use until the $13^{\text {th }}$ century. Taking it for granted that the gutters did not affect substantially the church's appearance, Viollet-le-Duc thought they ought to be kept unlike the anachronistic yet still Gothic single vault that destroyed the unity of a church aisle without any structural advantage. He would not accept gas lighting, because there were alternatives that would not interfere with the building's original fabric. Nevertheless, he would not mind the introduction of heating equipment, for no churchgoer should get a cold because of archeology; and then the required chimney should not be dissimulated, but taken advantage of, this material need turned into a decoration motif all evidence suggesting a preference for formal gradation rather than contrast.

By the same token, the addition to a modern fabric of newer technological improvements leading to greater livability should not be condemned, although the introduction of central air conditioning equipment in a minimalist building is usually problematic. In its eagerness to symbolise modernity, modern architects condemned as decoration many technologically useful building elements, as sharp critics remarked (Piacentini 1931, 528-539; Perret 1936, 238-239). As a rule, until the 1950s modern architecture lacked poché, the redundancy of material, mass and cavities that makes it easy to add up-to-date ducts to pre-modern architecture. All the same, there is an enormous difference between treating the design of ducts as an autonomous variable within a minimalist envelope and sub-ordinating it to the compositional logic of the building, which at the end of the day is clearly more relevant than unity of style. After all, mastermind Costa defined architecture as 'construction conceived with the intention of ordering and organising space in a plastic way correlated with a given epoch, a given milieu, a given technology, and a given program' (Costa 1962a, 113) and observed that 'the contemporary architecture said modern is not a mere question of license, or of improvisation due to personal caprice' (Costa 1962b, 199), but 'the masterly, correct and magnificent play of volumes brought together in light,' to use the words of his own master (Le Corbusier 2004, front cover), and 'correct' suggests that a regime of freedom-free plan, and free façade-does not dispense constraints the paralysed section, according to Colin Rowe (Rowe 1976, 140-158). The issue with the ducts at the renovated Oca and Dance Hall is that they are at odds with the strong geometries and the free plan concept of the original projects, unlike, for instance, as pointed out, the ducts at MAM-Rio; if there is no need to make a fetish of spatial continuity, its total obliteration amounts to deplorable architectural impoverishment at Palácio do Planalto and Palácio da Agricultura converted into MACUSP. More sympathetic interventions that do not rule out desirable retrofit are easy to envisage in all cases.

Costa was quick to point out the responsibility of the modern architect regarding design decisions. He called into question two opposite stands regarding the generation of modern architectural form: on the one hand, its techno-programmatic determination; on the other hand, its derivation from the designer's intuition operating in a cultural vacuum. In this sense, the opposition between Boito and Viollet-le-Duc is very real. For Viollet-le-Duc did not dissimulate his authorial condition, while Boito paraded neutrality as the restorer's ethical obligation, based on the concept of material authenticity. Regardless of Costa's stand on this debate, it is far from being settled. In Italy, the Carta della conservazione e del restauro degli oggetti d'arte e di cultura of 1987 replaced the Carta del restauro of 1972 (Marconi 1993, 207-228). The latter was shaped by Boito's critical-conservative heirs like Giuseppe Carbonara. The former was coordinated by Paolo Marconi, who defended Viollet-le-Duc's stylistic restoration against the proliferation of 'decorative and structural patchworks.' Nevertheless, in situations such as the retrofits discussed here, there is no need to take a stand on that debate to realise that the 'neutrality' of the reviewers is far from inconsequential and amounts to pure irresponsibility: the unnecessary sacrifice of integrity to livability, and artistic to historical values is not conservation.

Masters of the Carioca and the Paulista schools are mostly gone nowadays; they cannot bully as Niemeyer once did. More modern buildings are likely to be listed, and the need will increase for reviewing and supervising the execution of restoration and/or retrofit projects. IPHAN and its complementary agencies could well prepare for 
these duties by analysing in depth past experiences, recognising failures and learning from them. Listing is not conservation, as observed, but it sets the guidelines for future interventions, and in that sense it affects them not unlike the first lineaments of an architectural program. Perhaps future listings should be more precise in the connection between the values that justify the conservation and those guidelines. And reviewers, it should be emphasised, are in one way or another co-authors of the projects they analyse. Their input is not literary; it bears on the project under scrutiny. Called to act as architectural critics, they ought to become architecturally literate and technologically savvy even if they did not train as architects. It is not so difficult, granted a minimum of spatial intelligence and a striving for quality, with a little help from centuriesold technologies like model-making and newer ones like photo-montage, particularly effective when put at the service of comparing alternatives. In its first years, SPHAN was able to hire young architects to do in-house projects. The Ouro Preto Grand Hotel was one of them, commissioned by the town mayor. Four projects were drawn in succession, first a neo-colonial pastiche that historicists loved by Carlos Leão, another member of the Ministry team; then three by Niemeyer, with Costa brought in as a counsel: a flat-roofed modern proposal which enthralled modern purists, a dual-pitched tiled roof variant, and the richer final solution already described, full of ambiguities, an architecture promoting 'both and' rather than 'either or'. There was no air conditioning involved, but there were issues of climactic control and services. The debate was intense, and it was not limited to theoretical generalities; it tackled the concrete architectural problem with both rigor and creativity. For instance, comparison between the projects relied also on photomontages with models, taken from the same viewpoint. It ended up with a novel solution where the new relates to the old both by similarity and graded difference, rather than stark contrast. (Comas 2002) The breakthrough was recognising that there is not one solution only, and that the process of choosing between alternative solutions is argumentative, implying divergence (consideration of different alternatives) and convergence (selection of one outcome only). Although the Grand Hotel was not a restoration, it might well be considered a retrofit in terms of the listed environment in which it would rise, and the process by which it became implemented relevant for both kinds of project.

\section{Notes}

1. Casa de Lucio Costa.

2. State of Rio Grande do Sul: DPHAE, then IPHAE1964/ State of Rio de Janeiro: DPHARJ, then INEPAC 1965/ State of São Paulo: CONDEPHAAT 1968/ State of Minas Gerais: IEPHA 1971/ State of Pernambuco: FUNDARPE 1971.

3. Carioca means native of Rio, Paulista, of São Paulo.

4. This is the corollary of higher life expectancy, postponement of professional retirement and overvaluation of originality in a culture that does not seem particularly interested in refinement within continuity.

5. Indeed, modern artists are often reluctant to regard their works as finished and no longer in their full possession; metaphorically, it is as if they were parents trying to curtail the autonomy of grown up children, or as if they were delaying delivery after selling their works.

6. According to the useful distinction between simple problems, compound problems, complex problems, and metaproblems, the latter defined in terms of an unspecified number of incalculable variables.

\section{References}

Artigas, Rosa, ed. 2007. Paulo Mendes da Rocha: Projetos 1999-2006. São Paulo: Cosac Naify.

Boito, Camillo. 1884. I Restauratori: conferenza tenuta al'Exposizione di Torino 7 Giugno 1884 [The Restorers: Conference Held at the Turin Exposition June 7th 1884]. Florence: G. Barbèra Editore.

Bonduki, Nabil, ed. 1999. Affonso Eduardo Reidy. São Paulo: ILBPMBardi; Lisboa: Blau.

Britto, Alfredo. 2015. Pedregulho: o sonho pioneiro da habitação social no Brasil [Pedregulho: the Pioneering Dream of Social Housing in Brazil]. Rio de Janeiro: Edições de Janeiro.

Cartwright, T.J. 1973. "Problems, Solutions and Strategies: A Contribution to the Theory and Practice of Planning." Journal of the American Institute of Planners 39 (3): 179-187.

Casa de Lucio Costa. 2018. "Document II.B.03-01468." Accessed June 6 2018. www.jobim.org/lucio/

Chuva, Marcia. 2009. Os arquitetos da memória: sociogênese das práticas de preservação do patrimônio cultural no Brasil (anos 1930-1940) [The Architects of Memory: Socio-Genesis of Practices of Preservation of Cultural Heritage in Brazil (1930-1940)]. Porto Alegre: UFRGS.

Cohen, Jean-Louis. 2004. Le Corbusier 1887-1965: The 
Lyricism of Architecture in The Machine Age. Bremen: Taschen.

Comas, Carlos Eduardo, Cecilia R. dos Santos and Ruth Verde Zein. 2008. "Beyond Oscar Niemeyer: Authorities, Remodellings, Paradoxes and Peculiarities in the Preservation of Modern Buildings in Brazil." In The Challenge of Change: Dealing with the Legacy of the Modern Movement. Proceeding of the Tenth Docomomo International Conference. Delft: Delft University Press.

Comas, Carlos Eduardo. 2002. Précisions brésiliennes sur un état passé de l'architecture et de l'urbanisme modernes [Brazilian Precisions on a Past State of Modern Architecture and Urbanism]. Paris: Université Paris 8.

Comas, Carlos Eduardo. 2007. "Rio, Pernambuco, Rio Grande e Minas; contextualismo e heteromorfismo na arquitetura moderna brasileira." In Arquitetura Moderna no Norte e Nordeste; universalidade e diversidade [Modern Architecture in the North and Northeast; Universality and Diversity], edited by Fernando Diniz Moreira. Recife: CECI/ Unicap.

Comas, Carlos Eduardo. 2015. "The Poetics of Development." In Latin America in Construction: Architecture 1955-1980, edited by Barry Bergdoll, Carlos Eduardo Comas, Jorge Francisco Liernur and Patricio del Real, 40-67. New York: MoMA.

Costa, Lúcio. 1962a. "Considerações sobre o ensino da arquitetura." [Considerations about Architecture Teaching] In Lúcio Costa: Sobre Arquitetura [Lúcio Costa: About Architecture], 111-117. São Paulo: Empresa das Artes, 1995.

Costa, Lúcio. 1962b. "Depoimento de um arquiteto carioca." [Testimony of A Carioca Architect] In Lúcio Costa: Sobre Arquitetura [Lúcio Costa: About Architecture], 169-201. Porto Alegre: CEUA.

Costa, Lucio. 1999. Documentos de trabalho, edited by José Pessoa. Rio de Janeiro: IPHAN.

Fonseca, Maria Cecilia Londres. 2005. O patrimônio em processo. Trajetória da política federal de preservação no Brasil [The Heritages in the Process. The Trajectory of the Federal Preservation Policy in Brazil]. Rio de Janeiro: UFRJ Editora.

Goodwin, Philip, and Kidder-Smith, G. E. 1943. Brazil Builds. Architecture New and Old. 1652-1942. New York: MoMA.

Ireland Department of Arts, Heritage and the Gaeltacht. 2011. "Conservation principles; Section 7.3: Keeping a Building in Use; Article 7.3.1." Chap.7 in Architectural Heritage Protection Guidelines for Planning Authorities. Accessed 6 June 2018. https://www.chg.gov.ie/app/
uploads/2015/07/Architectural-Heritage-ProtectionGuidelines-2011.pdf

Kuhl, Beatriz Mugayar. 2006. "Preservação da arquitetura moderna e metodologia de restauro." [Preservation of Modern Architecture and Restoration Methodology] Pós 19: 199-201.

Marconi, Paolo. 1993. Il restauro e l'architetto. Teoria e pratica in due secoli di debattito [The Restoration and the Architect: Theory and Practice in Two Centuries of Debate]. Venezia: Marsilio Edittori.

Mindlin, Henrique. 1956. Modern Architecture in Brazil. Rio de Janeiro: Colibris Editora.

Motta, Lia. 1987. "A SPHAN em Ouro Preto: uma história de conceitos e critérios." [SPHAN in Ouro Preto: A History of Concepts and Criteria] Revista do IPHAN 22: $108-122$.

Papadaki, Stamo. 1956. Oscar Niemeyer: Works in Progress. New York: Reinhold Publishing Company.

Perret, Auguste. 1935. "O que é arquitetura." Arquitetura e urbanismo Nov-Dec: 238-239.

Piacentini, Marcelo. 1930. "Dove è irragionevole l'archittettura razionale." [Where Rational Architecture Is Unreasonable] Dedalo 11 (2): 528-539.

Ronca, Paola, Alberto Franchi, and Antonio Migliacci. 2009. Open Issues for the Conservation of Landmark Modern Architecture: the Case Study of Torre Velasca. In Protection of Historical Buildings PROHITECH 09: Proceedings of the International Conference on Protection of Historical Buildings, edited by Federico M. Mazzolani, 557-562. Boca Raton, Florida: CRC Press, Inc..

Ronca, Paola, Pietro Giuseppe Crespi, Alberto Franchi, and Alessandro Zichi. 2009. "Il patrimonio architettonico del moderno: conservazione e durabilita' per Torre Velasca." [The Modern Architectural Heritage: Conservation and Durability for Torre Velasca] http:// www.cias-italia.it/PDF/58.pdf

Rowe, Colin. 1976. "Neoclassicism and Modern Architecture II." In The Mathematics of the Ideal Villa and Other Essays, 140-158. New Haven: MIT Press.

Ruskin, John. 1849. The Seven Lamps of Architecture. London: Smith, Elder \& Co..

Salvo, Simona. 2002. "Il restauro del grattacielo Pirelli: Una questione internazionale, un intervento italiano." [The Restoration of the Pirelli Skyscraper: An International Question, an Italian Intervention] In Grattacielo Pirelli: indagini sulle fonti documentarie e sulle esperienze internazionali [Pirelli Skyscraper: Surveys on Documentary Sources and International Experiences]. Milano: Assessorato per le Identità, le Culture e 
le Autonomie della Regione Lombardia.

Salvo, Simona. 2006. "A restauração do edifício Pirelli: a resposta italiana a uma questão internacional." [The Restoration of the Pirelli Building: The Italian Answer to an International Question] Pós 19: 201-210.

Salvo, Simona. 2008. "A intervenção na arquitetura contemporânea como tema emergente do restauro." [The Intervention in Contemporary Architecture as an Emerging Theme of Restoration] Pós 23: 199-211.

Scharlach, Cecilia, ed. 2006. Oscar Niemeyer: a marquise e o projeto original do Parque Ibirapuera [Oscar Niemeyer: The Marquee and the Original Project of the Ibirapuera Park]. São Paulo: Imprensa Oficial.

Schlee, Andrey, ed. 2017a. IPHAN 1937-2017. Special issue. Revista do Patrimônio Histórico e Artístico Nacional 35.

Schlee, Andrey, ed. 2017b. Patrimônio: desafios e perspectivas." [Heritage: Challenges and Perspectives] Revista do Patrimônio Histórico e Artístico Nacional 36.

SPBR. 2018. "Reforma da Oca." Accessed May 312018. www.spbr.arq.br/portfolio-items/reforma-da-oca/

Summerson, John. 1963. “The Mischievous Analogy.” In Heavenly Mansions, 195-218. New York: Norton.

Viollet-le-Duc, Eugène-Emmanuel. 1866. "Restauration.” In Dictionnaire raisonné de l'architecture française $d u$ XIe au XVIe siècle. t. VIII. Paris: Bance- Morel.

Viollet-le-Duc, Eugène-Emmanuel. 1875. On Restoration. Translated by Charles Wethered. London: Sampson Low, Marston, Low and Searle.

Zein, Ruth Verde. 2005. "A arquitetura da escola paulista brutalista 1953-73" [The Architecture of the Brutalist Paulista School]. PhD diss., Federal University of Rio Grande do Sul. 